\title{
Serum Albumin Measurement
}

National Cancer Institute

\section{Source}

National Cancer Institute. Serum Albumin Measurement. NCI Thesaurus. Code C61015.

A quantitative measurement of the amount of albumin present in a sample of serum. 